\title{
THE INFLUENCE OF DIFFERENT SCREW TIGHTENING FORCES ON THE VERTICAL MISFIT OF IMPLANT-SUPPORTED FRAMEWORKS
}

\author{
AVALIAÇÃO DO EFEITO DA FORÇA DE APERTO DE PARAFUSOS DE RETENÇÃO \\ NA DESADAPTAÇÃO MARGINAL DE PRÓTESES SOBRE IMPLANTES
}

\author{
Diego Klee de VASCONCELLOS ${ }^{1}$, Marco Antonio BOTTINO ${ }^{2}$, Renato Sussumu NISHIOKA ${ }^{3}$, \\ Luiz Felipe VALANDRO ${ }^{1}$, Elza Maria Valadares da COSTA $^{1}$
}
1- DDS, MSc, PhD, Graduate Student (PhD degree), Department of Dental Materials and Prosthodontics, UNESP - São Paulo State University "Júlio de Mesquita Filho" - São José dos Campos Dental School.
2- DDS, MSc, PhD, Associate Professor, Department of Dental Materials and Prosthodontics, UNESP - São Paulo State University "Júlio de Mesquita Filho" - São José dos Campos Dental School.
3- DDS, MSc, PhD, Assistant Professor, Department of Dental Materials and Prosthodontics, UNESP - São Paulo State University "Júlio de Mesquita Filho" - São José dos Campos Dental School.

\begin{abstract}
Corresponding address: UNESP - São Paulo State University “Júlio de Mesquita Filho” São José dos Campos Dental School.
Department of Dental Materials and Prosthodontics - Eng. Francisco José Longo Av., 777 - Jardim São Dimas

São José dos Campos, São Paulo 12245000 - Brazil - Phone \#: 55-12-39233819 Fax: 551239479010 - e-mail: diegokv@terra.com.br
\end{abstract}

Received: May 24, 2004 - Modification: September 28, 2004 - Accepted: October 13, 2004

\begin{abstract}
O

bjectives: The present in vitro study was designed to compare the differences in the vertical misfit of implant-supported frameworks using three different forces for tightening the bridge locking screws: fastening by hand until first resistance, and using torque drivers with 10 and $20 \mathrm{Ncm}$. Methods: The investigation was conducted based on the results given by 9 six-unit nickel-chromium ( 2 abutments/ 4 pontics) screw-retained implant-supported frameworks. The structures were exposed to simulated porcelain firings. The marginal misfit measurements were made using a traveling measuring microscope at selected screw tightening forces: fastening by hand until first resistance, and using torque drivers with 10 and $20 \mathrm{Ncm}$. The results were submitted to one-way ANOVA with repeated measures on one factor, and post hoc pairwise comparisons using Tukey test (5\%).

Results: The mean marginal misfit of the frameworks, fastening the screws by hand until first resistance, was $41.56 \mu \mathrm{m}(\mathrm{SD} \pm 12.45 \mu \mathrm{m})$. The use of torque driver devices caused a significant reduction in marginal opening $(\mathrm{p}<0.05)$. With the lowest torque available $(10 \mathrm{Ncm})$, the mean marginal discrepancy at the abutment-framework interface was reduced an average of 52\% to a mean marginal opening of $19.71 \mu \mathrm{m}$ (SD $\pm 2.97 \mu \mathrm{m})$. After the use of the $20 \mathrm{Ncm}$ torque driver, the mean marginal discrepancy of the frameworks was reduced an average of $69 \%$ to a mean marginal opening of $12.82 \mu \mathrm{m}(\mathrm{SD} \pm 4.0 \mu \mathrm{m})$. Comparing the use of torque drivers with 10 and $20 \mathrm{Ncm}$ torque, the means are not significantly different from one another. Conclusion: The seating force has an important effect on the vertical misfit measurements, once it may considerably narrow the vertical misfit gaps at the abutment-framework interface, thus leading to a misjudgment of the real marginal situation.

Uniterms: Dental implants; Osseointegration; Implant-supported dental prosthesis; Torque, misfit.
\end{abstract}

\begin{abstract}
RESUMO
$O$

presente estudo avaliou o efeito da força de aperto de parafusos de retenção na desadaptação marginal de próteses sobre implantes. A investigação foi conduzida baseada em resultados fornecidos por nove estruturas metálicas implanto-suportadas de seis elementos (02 retentores e 04 pônticos), retidas por parafusos. A mensuração da desadaptação marginal foi realizada com auxílio de microscópio óptico, nos seguintes momentos: M1: aperto com chave manual até a primeira resistência do parafuso; M2: aperto utilizando torquímetro mecânico com 10Ncm e M3: aperto utilizando torquímetro mecânico com $20 \mathrm{Ncm}$. As médias de desadaptação foram submetidas à análise estatística (ANOVA e Tukey). O emprego de torquímetros mecânicos, independente do valor de torque, determinou redução significativa na abertura marginal $(\mathrm{p}<0,05)$. A

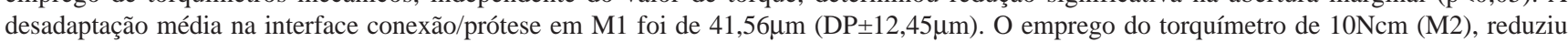
$52 \%$ desta fenda marginal, para uma média de desadaptação de 19,71 $\mu \mathrm{m}$ (DP $\pm 2,97 \mu \mathrm{m})$; enquanto o torquímetro de 20Ncm (M3) reduziu 69\% da desadaptação marginal, para uma média de $12,82 \mu \mathrm{m}(\mathrm{DP} \pm 4,0 \mu \mathrm{m})$ os de retenção de próteses implanto-suportadas tem importante efeito na mensuração da desadaptação marginal, uma vez que pode modificar consideravelmente as aberturas na interface conexão/prótese.

Unitermos: Implantes dentários; Osseointegração; Prótese dentária fixada por implante; Torque, desadaptação.
\end{abstract}




\section{INTRODUCTION}

Implant restorations can be either screw or cementretained. Screw-retained designs have a well-documented history of success. Implant biomechanics investigations have focused on this kind of restoration, which is designed to provide predictable retrievability and abutment-restorative joint integrity ${ }^{9,18}$.

An accurate fit between the implant abutment and the superstructure in screw-retained implant prostheses is very important. Poorly fitting implant frameworks can potentially cause uneven thread contact, tension, and bending stresses of the connecting screw, therefore resulting in screw loosening and fractures, and marginal peri-implant bone loss ${ }^{3}$. These problems are induced by static forces caused by the tension in the bridge locking screws when securing a misfitting framework to the implants ${ }^{12}$.

The seating force used to place the frameworks on the abutments may have an important effect in vertical measurement investigations. A large range of seating forces has been used in previous fit studies ${ }^{3,23,28}$, but no optimal value has been proposed. The use of torque drivers to tighten the superstructure screws, even with the lowest torque available $(10 \mathrm{Ncm})$ using the manufacturer's torque driver, may considerably narrow the vertical misfit gaps at the abutment-to-cylinder interface. In vitro studies have shown that vertical gaps may be closed by flexure in the framework and anchorage unit components when the bridge locking screws are tightened to the correct preload level $12,17,21$.

This significant decrease in the marginal opening from screw tightening is associated with higher stress in screwretained restorations leading to a misjudgment of the real marginal situation and substantially increasing the fatigue of the components, resulting in loosening or fracture of the prosthesis or abutment screws, distortion or breakage of the restoration, and marginal peri-implant bone loss ${ }^{9,28}$.

The present in vitro study was designed to compare the differences in the vertical misfit of implant-supported frameworks using three different forces for tightening the bridge locking screws: fastening by hand until first resistance, and using torque drivers with 10 and $20 \mathrm{Ncm}$.

\section{MATERIALS AND METHODS}

The condition simulated for evaluation in this study was a mandibular anterior quadrant to be restored with a six-unit FPD screw-retained on implants. An acrylic resin model (Figure1) was fabricated with two external hex cylinder implants (4.0 mm diameter, 15.0 mm length; Master Screw Conexão Sistemas de Prótese - São Paulo, Brazil) placed in the right and left canine area (sites 33 and 43), parallel and $22 \mathrm{~mm}$ apart from each other from center to center. This model served as an index for marginal misfit measurements. Abutments were connected to the implants (Micruscone 138023 - Conexão Sistemas de Prótese - São Paulo, Brazil) by fastening screws with a torque wrench using $20 \mathrm{Ncm}$ torque. Impression posts (141000 - Conexão Sistemas de Prótese - São Paulo, Brazil) were attached to the abutments, and a silicone impression (Express - 3M - São Paulo, Brazil) was made using a custom resin tray suitable for the master cast. After the impression posts and the abutment analogs (143000 - Conexão Sistemas de Prótese - São Paulo, Brazil) were connected, they were returned to the impression, which was poured in stone (Durone - Dentsply - Petrópolis, Brazil) to make the working cast.

Ten implant-supported frameworks were fabricated on the working cast. For fabrication of standardized wax pattern for the FPD, the castable plastic cylinders (149001 - Conexão Sistemas de Prótese - São Paulo, Brazil) were placed on the analogues and hand tightened until resistance was felt. Teeth were fashioned in inlay wax in an anatomically correct manner. A condensation silicone mold (Express - 3M - São Paulo, Brazil) was fashioned over this FPD wax pattern to allow for multiple FPD pattern replications.

The investment, burnout and casting techniques were standardized. Patterns were sprued and invested in pairs in a phosphate-bonded investment (Belavest SH - Bego Bremen, Germany) according to a 1-piece casting technique. Following bench curing and burnout, the investment rings were cast in a nickel-chromium alloy (Wironia - BegoBremen-Germany).

Divesting was completed in the usual manner with minimum use of aluminum oxide air abrasives on critical interfaces. Burs were used under laboratory microscope to eliminate internal casting inaccuracies. Protective polishing caps (abutment analogues - 143000 - Conexão Sistemas de Prótese - São Paulo, Brazil) covered the interfaces and reduced the risk of inaccuracy. In this occasion, one FPD was discarded because of casting problems.

Nine frameworks (Figure 2) were exposed to six simulated porcelain-firing cycles (two opaque firings, three body firings, and one glaze firing). However, porcelain was not applied. All samples were allowed to cool to room temperature before the next firing cycle began.

The marginal misfit measurements were made using a traveling measuring microscope (Sprint 100 - RAM Optical Instrumentation - Irvine, CA - USA). Six marks were made

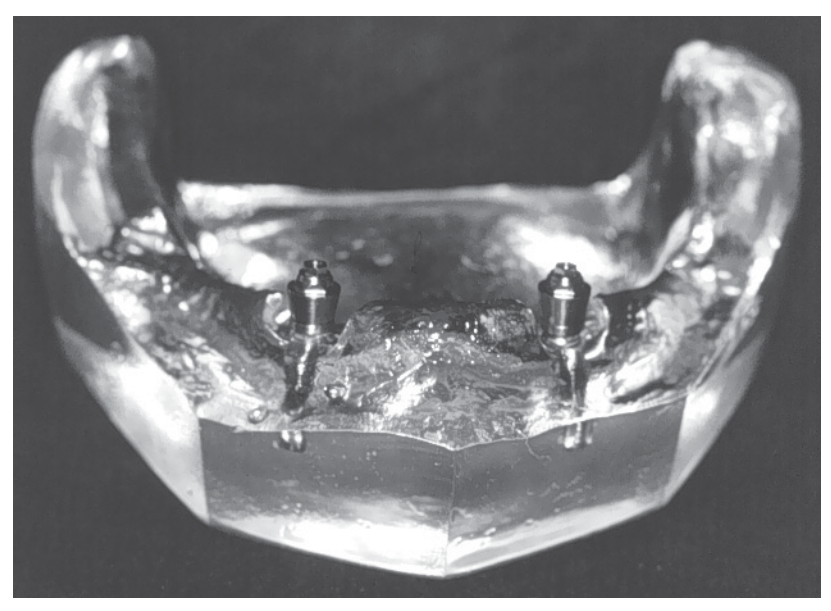

FIGURE 1- Acrylic resin model with two external hex cylinder implants. Abutments were connected to the implants 
in each abutment to standardize the microscope measurement points. Three were made on the buccal surface and three on the lingual surface, adding up to twelve reading points for each framework. The frameworks were positioned on the abutments of the acrylic resin model by fastening titanium screws, always by the same investigator, using three different forces for tightening the bridge locking screws:

1. Using a hand-operated screwdriver (060300 Conexão Sistemas de Prótese - São Paulo, Brazil) until the screws started to offer resistance, based on tactile sensation;

2. Using a mechanical torque-controlling device with 10Ncm (400000 - Conexão Sistemas de Prótese - São Paulo, Brazil);

3. Using a mechanical torque-controlling device with 20Ncm (400000 - Conexão Sistemas de Prótese - São Paulo, Brazil).

Measurements were made for the three different torque moments. The marginal gap size was measured in micrometers under 230x magnification (Figure 3). Data were analyzed to determine the mean marginal openings and standard deviations for each of the 9 FPD using the three different tightening forces. The results were submitted to RM ANOVA and Tukey test (5\%).

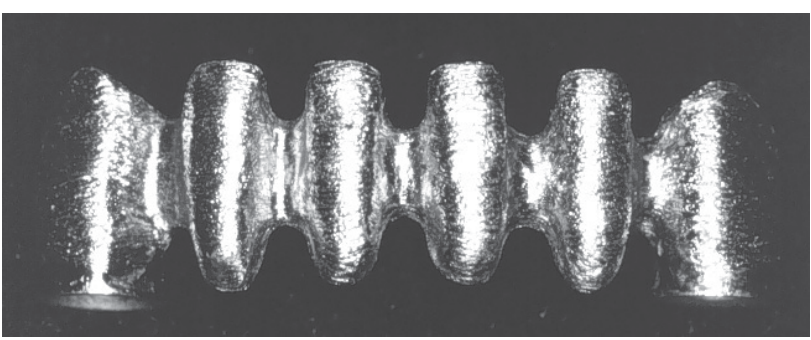

FIGURE 2- Labial view of cast framework

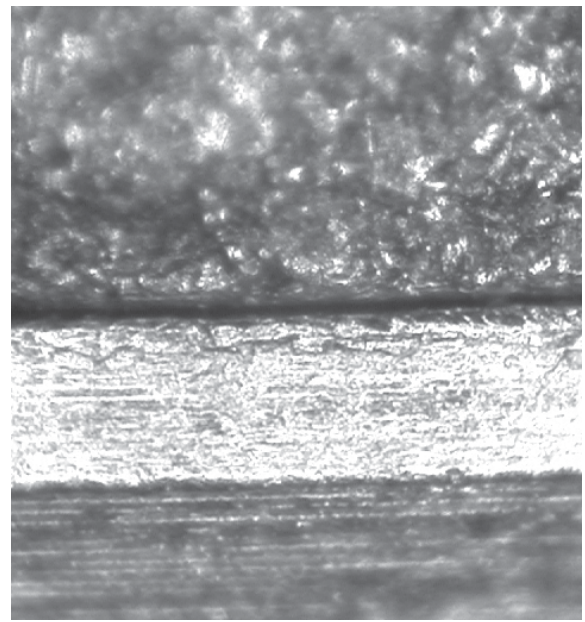

FIGURE 3- Vertical misfit gap size at the abutmentframework interface, measured under 230x microscope magnification (abutment is below)

\section{RESULTS}

The mean marginal misfits of the frameworks (in micrometers), using the three different forces for tightening the bridge locking screws, are summarized in Table 1 . The mean marginal opening, fastening the screws by hand until first resistance, was $41.56 \mu \mathrm{m}$ ( $\mathrm{SD} \pm 12.45 \mu \mathrm{m})$. Upon screw tightening using torque driver devices, margins closed significantly (RM ANOVA, $\left.\mathrm{F}_{\mathrm{df}(2 ; 16)}=49.40 ; \mathrm{p}=0.001\right)$. With the lowest torque available $(10 \mathrm{Ncm})$, the mean marginal discrepancy at the abutment-framework interface was reduced an average of $52 \%$ to a mean marginal opening of $19.71 \mu \mathrm{m}(\mathrm{SD} \pm 2.97 \mu \mathrm{m})$. After the use of the $20 \mathrm{Ncm}$ torque driver, the mean marginal discrepancy of the frameworks was reduced an average of $69 \%$ to a mean marginal opening of $12.82 \mu \mathrm{m}(\mathrm{SD} \pm 4.0 \mu \mathrm{m})$. Comparing the use of torque drivers with 10 and $20 \mathrm{Ncm}$ torque, the means are not significantly different from one another (Figure 4).

\section{DISCUSSION}

The seating force has an important effect on the vertical misfit measurements, since it may considerably narrow the vertical misfit gaps at the abutment-framework interface ${ }^{9,12,28}$. Few studies have attempted to correlate implant prostheses misfit related to different seating forces used to place the samples on the abutments before microscope measurements. A large range of seating forces has been used in previous fit

TABLE 1- Mean values and standard deviations of vertical misfit of samples, using three different forces for tightening the bridge locking screws

\begin{tabular}{lccc}
\hline FORCES & N & MEANS & SD \\
& & & \\
Manual & 9 & $41.569 \mu \mathrm{m}$ & $\pm 12.450 \mu \mathrm{m}$ \\
$10 \mathrm{NCm}$ & 9 & $19.717 \mu \mathrm{m}$ & $\pm 2.9773 \mu \mathrm{m}$ \\
$20 \mathrm{Ncm}$ & 9 & $12.820 \mu \mathrm{m}$ & $\pm 4.0007 \mu \mathrm{m}$ \\
\hline
\end{tabular}

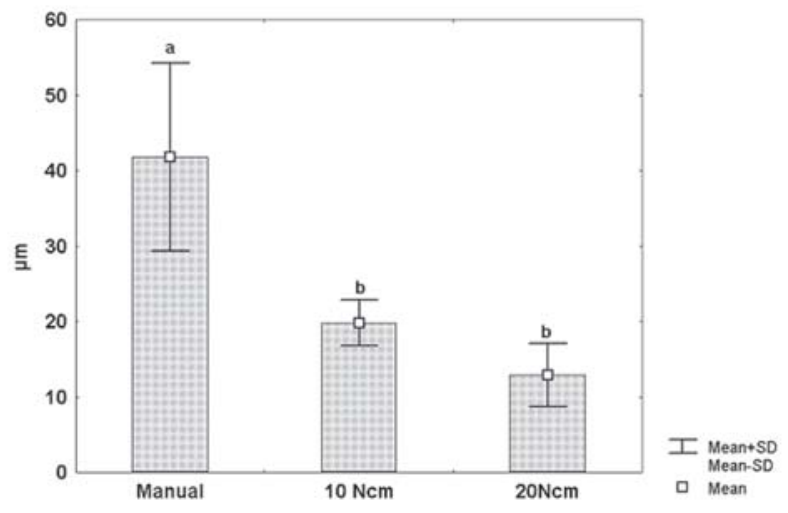

FIGURE 4- Graphic presentation of mean marginal misfit for each force used. Columns with the same letter do not differ one from the other at $5 \%$ level of significance (Tukey test) 
studies ${ }^{3,23,28}$, but no optimal value has been proposed.

When two components are tightened together by a screw, this unit is called a screw joint. The clamping force needed to keep the components tightly together under static and dynamic conditions is called preload ${ }^{1,22}$. When the prosthesis does not make complete contact with the abutment, there will be a gap between all or part of the matching surfaces. If there is no contact, the preload is used to bring the matching surfaces closer together, and perhaps into contact. In this situation, virtually no fatigue protection is obtained because any external load applied to separate the prosthesis from the abutment causes further tension in the screw and is not dissipated by relieving compressive stresses in the clamped parts, resulting in screw loosening and fractures $3,13,28$. The introduction of a $100 \mathrm{~mm}$ discrepancy in the in vitro model results in a change in the external preload (the static axial force and bending moment acting between the implant and the prosthetic construction due to misfit) of approximately $200 \mathrm{~N}$ per abutment ${ }^{21}$.

In the present investigation, microscopic evaluation of the marginal discrepancy was used to determine whether differences existed between three screw tightening forces (fastening by hand until first resistance, and using torque drivers with 10 and $20 \mathrm{Ncm}$ ) used to place the frameworks on the abutments, prior to the microscope measurements. Measurement data were obtained by positioning the samples under the microscope so that the marginal area of the implant-restoration junction was viewed from a directly perpendicular perspective. Other investigators ${ }^{10,14,15,28}$ have also used this methodology. It allows the measurement of marginal discrepancy in a nondestructive format with multiple readings on the samples. Although there are many ways to assess three-dimensional fit of prostheses to abutments, the sophisticated testing equipment required for such testing is not readily available $\mathrm{e}^{10,12}$. The use of more common measuring techniques still provides information on the relative fit or misfit of prosthesis while recognizing the fact that this is not as precise as the other methods ${ }^{10}$.

The results of this investigation showed that the use of a torque driver, even with the lowest torque available (10Ncm), may considerably narrow the vertical misfit gaps at the abutment-framework interface. Mean marginal opening, fastening the screws by hand until first resistance, was $41.56 \mu \mathrm{m}(\mathrm{SD} \pm 12.45 \mu \mathrm{m})$. Screw tightening using torque driver devices caused a significant closure in the mean marginal openings $(\mathrm{p}<0.05)$. With the lowest torque available $(10 \mathrm{Ncm})$, the mean marginal discrepancy at the abutmentframework interface was reduced an average of 52\% to a mean marginal opening of $19.71 \mu \mathrm{m}(\mathrm{SD} \pm 2.97 \mu \mathrm{m})$. After the use of the $20 \mathrm{Ncm}$ torque driver, the mean marginal discrepancy of the frameworks was reduced an average of $69 \%$ to a mean marginal opening of $12.82 \mu \mathrm{m}(\mathrm{SD} \pm 4.0 \mu \mathrm{m})$. Comparing the use of torque drivers with 10 and $20 \mathrm{Ncm}$ torque, the means are not significantly different from one another. There seems to be a positive relation between the torque used for tightening the screws and the amount of vertical discrepancy. The results of this study compared favorably with prior studies evaluating marginal adaptation
$9,12,14,17,28$

Using a 3-D photogrammetric technique to measure distortion of 3-unit implant frameworks and bone surrounding osseointegrated implants, other investigators 12 showed that the mean displacement of the frameworks, measured in the direction of the long axis of the cylinder, was $177 \mu \mathrm{m}$ (range from $100 \mu \mathrm{m}$ to $300 \mu \mathrm{m}$ ). These levels of distortion are higher than the levels reported in this investigation using comparable screw preload. However, variations in framework stiffness, as well as in positions of the implants in the different studies, may well explain these differences. The authors also identified a vertical movement of the implant head up towards the framework, of a mean magnitude of $123 \mu \mathrm{m}$ (range $60 \mu \mathrm{m}$ to $200 \mu \mathrm{m}$ ). Consequently, by considering both the flexure of the metal frame, as well as the bone strain, they assumed that gaps, even wider than $100 \mu \mathrm{m}$, could somehow be closed in clinical situations by means of tightening the bridge locking screws.

In the present investigation, the vertical movement that narrows the marginal gaps probably occurred because of the displacement of the frameworks in the direction of the cylinder, since the index model used as an implant receptor for this in vitro study was fabricated using a thermoactivated acrylic resin that does not have the same flexural behavior as the human bone. The mean displacement of the frameworks measured in the direction of the long axis of the cylinder was $21.85 \mu \mathrm{m}$ after the use of the $10 \mathrm{Ncm}$ torquecontrolling device, and $28.74 \mu \mathrm{m}$ after the use of the $20 \mathrm{Ncm}$ torque-controlling device.

The accuracy with which persons can achieve a specified torque $(10,20$ and $32 \mathrm{Ncm})$ on the appropriate implant component with hand-held screwdrivers has been examined $3,8,22$. The investigators found a wide variation in the ability of clinicians to perceive torque. These studies indicated the unsteady torque that hand-held screwdrivers may apply. The results observed in the present study support the fact that marginal misfit investigations, in which screws are fastened by hand, always by the same investigator, until the first resistance is met ${ }^{27,28}$, allows a more real fit evaluation, since no attempt is made to narrow the vertical misfit gaps. However, it seems to be a risky protocol, due to the difficulty in standardizing the screw tightening procedure prior to microscope measurements ${ }^{3,22,25}$. The fabrication of a special torque driver to reduce the lower torque, as previously suggested ${ }^{23}$, may standardize the screw tightening without considerable influence on the vertical misfit gaps. Future research may be directed towards evaluation of this method.

The popularity of base metal alloys (nickel-chromium and cobalt-chromium) has dramatically increased in recent years because of their advantageous mechanical properties and due to the high cost of gold and palladium. The superior yield strength (resistance to permanent deformation), and higher elastic modulus (rigidity) allow a more uniform stress distribution within the framework, providing a more efficient and durable load transfer. The use of a more rigid material for the framework of osseointegrated prosthesis decreases the stress within the prosthesis retaining screws. This probably means that the high resistance of the framework 
to bending reduces the risks of mechanical overloading for the retaining screws, especially for the cantilevered superstructures ${ }^{20,26}$.

Based on previous articles ${ }^{5,11,16,19,28}$, which indicated a certain biological tolerance for prosthetic misfits in the living bone, the vertical gaps recorded in the present study, using torque drivers with 10 and $20 \mathrm{Ncm}$, would probably not be clinically distinguishable, and would not lead to clinical problems, even with the frameworks being fabricated by a one-piece cast method instead of the soldering method which would markedly improve the marginal fit 15,24,27.

Previous investigations found that porcelain application had no effect on casting distortion ${ }^{2,4,6,7}$; thus, the presence of the ceramic would not modify the results of the present research.

Stress introduced into the implant system as a result of prosthesis misfit may be present many years after placement. This observation supports the concern for the precision of frameworks with regard to various aspects of fatigue in the long-term perspective. Accurate, reliable, and verifiable methods to improve and precisely evaluate fit are still needed.

\section{CONCLUSION}

The seating force has an important effect on the vertical misfit measurements. The results of this investigation showed that the use of a torque driver, even with the lowest torque available $(10 \mathrm{Ncm})$, may considerably narrow the vertical misfit gaps at the abutment-framework interface. This significantly decrease in the marginal opening from screw tightening is associated with higher stress in the screwretained restorations leading to a misjudgment of the real marginal situation, substantially enhancing the fatigue of the components.

\section{ACKNOWLEGDEMENTS}

The authors would like to express their gratitude to José Luiz Batista for his help in preparing the test samples. All equipment and materials used in this research were kindly supplied by CONEXÃO and WILCOS Companies. This research was conducted at the Department of Dental Materials and Prosthodontics of UNESP - São Paulo State University “Júlio de Mesquita Filho”, São José dos Campos Dental School . Dr. Ivan Balducci performed statistical analyses.

\section{REFERENCES}

1- Alkan I, Sertgoz A, Ekici B. Influence of occlusal forces on stress distribution in preloaded dental implant screws. J Prosthet Dent 2004 Apr;91(4):319-25.

2- Anusavice KJ, Carroll JE. Effect of incompatibility stress on the fit of metal ceramic crowns. J Dent Res 1987;66 (8):1341-5.
3- Burguete RL, Johns RB, King T, Patterson EA. Tightening characteristics for screwed joints in osseointegrated dental implants. J Prosthet Dent 1994;71(6):592-9.

4- Campbell SD, Pelletier LB. Thermal cycling distortion of metal ceramics: Part I - metal collar width. J Prosthet Dent 1992;67(5):603-

5- Carr AB, Gerard DA, Larsen PE. The response of bone in primates around unloaded dental implants supporting prostheses with different levels of fit. J Prosthet Dent 1996;76(5):500-9.

6- De Hoff PH, Anusavice KJ. Effect of metal design on marginal distortion of metal-ceramic crowns. J Dent Res 1984;63(11):132731

7- Fonseca JC, Henriques GE, Sobrinho LC, de Goes MF. Stressrelieving and porcelain firing cycle influence on marginal fit of commercially pure titanium and titanium-aluminum-vanadium copings. Dent Mater 2003 Nov;19(7):686-91.

8- Goheen KL, Vermilyea SG, Vossoughi J, Agar JR. Torque generated by handheld screwdrivers and mechanical torquing devices for osseointegrated implants. Int J Oral Maxillofac Implants 1994 MarApr;9(2):149-55.

9- Guichet DL, Caputo AA, Choi H, Sorensen JA. Passivity of fit and marginal opening in screw-or cement-retained implant fixed partial denture designs. Int J Oral Maxillofac Implants 2000;15(2):239-46.

10- Hecker DM, Eckert SE. Cyclic loading of implant-supported prostheses: changes in component fit over time. J Prosthet Dent 2003 Apr;89(4):346-51.

11- Jemt T, Book K. Prosthesis misfit and marginal bone loss in edentulous implant patients. Int J Oral Maxillofac Implants 1996;11(5)620-5.

12- Jemt T, Lekholm U. Measurements of bone and framework deformations induced by misfit of implant superstructures: a pilot study in rabbits. Clin Oral Implants Res 1998;9(4):272-80.

13- Kallus T, Bessing C. Loose gold screws frequently occur in fullarch fixed prostheses supported by osseointegrated implants after 5 years. Int J Oral Maxillofac Implants 1994;9(2):169-78.

14- Keith SE, Miller BH, Woody RD, Higginbottom FL. Marginal discrepancy of screw-retained and cemented metal-ceramic crowns on implants abutments. Int $\mathrm{J}$ Oral Maxillofac Implants 1999;14(3):369-78.

15- Koke U, Wolf A, Lenz P, Gilde H.In vitro investigation of marginal accuracy of implant-supported screw-retained partial dentures. J Oral Rehabil 2004 May;31(5):477-82.

16- Michaels GC, Carr AB, Larsen PE. Effect of prosthetic superstructure accuracy on the osseointegrated implant bone interface. Oral Surg Oral Med Oral Pathol Oral Radiol Endod 1997; 83(2):198205.

17- Millington ND, Leung T. Inaccurate fit of implant superstructures. Part 1: Stresses generated on the superstructure relative to the size of fit discrepancy. Int J Prosthodont 1995; 8(6):511-6.

18- Rangert B, Jemt T, Jorneus L. Forces and moments on Branemark implants. Int J Oral Maxillofac Implants 1989;4(3):241-7

19- Sahin S, Cehreli M. The significance of passive framework fit in implant prosthodontics: current status. Implant Dent 2001;10(2):85-92. 
20- Sertgoz A. Finite element analysis study of the effect of superstructure material on stress distribution in an implant-supported fixed prosthesis. Int J Prosthodont 1997;10(1):19-27.

21- Smedberg JI, Nilner K, Rangert B, Svensson SA, Glantz SA.On the influence of superstructure connection on implant preload: a methodological and clinical study. Clin Oral Implants Res 1996;7(1):55-63.

22- Tzenakis GK, Nagy WW, Fournelle RA, Dhuru VB. The effect of repeated torque and salivary contamination on the preload of slotted gold implant prosthetic screws. J Prosthet Dent 2002 Aug;88(2):18391.

23- Vasconcellos DK, Cardoso AC, Bottino MA, Magini RS, Adriani Jr WA. High temperature dimensional alterations of implant supported frameworks. Braz J Oral Sci 2005 Jan-Mar;4(12):689-94.

24- Watanabe F, Uno I, Hata Y, Neuendorff G, Kirsch A. Analysis of stress distribution in a screw-retained implant prosthesis. Int J Oral Maxillofac Implants 2000 Mar-Apr;15(2):209-18.

25- Winkler S, Ring K, Ring JD, Boberick KG. Implant screw mechanics and the settling effect: overview. J Oral Implantol 2003;29(5):242-5.

26- Wu Y, Moser JB, Jameson LM, Malone WF. The effect of oxidation heat treatment on porcelain bond strength in selected base metal alloys. J Prosthet Dent 1991 Oct;66(4):439-44.

27- Yanase RT, Binon PP, Jemt T, Gulbransen HJ, Parel S. Current Issues Forum. How do you test a cast framework fit for a full-arch fixed implant-supported prosthesis? Int J Oral Maxillofac Implants 1994;9(4):469-74.

28- Zervas PJ, Papazoglou E, Beck FM, Carr AB. Distortion of three-unit implant frameworks during casting, soldering, and simulated porcelain firings. J Prosthodont 1999 Sep;8(3):171-9. 